\title{
ANALISIS PERBANDINGAN INTERPRETASI PENOKOHAN ANTARA NOVEL DAN FILM 99 CAHAYA DI LANGIT EROPA
}

\author{
Suryanto \\ Program Studi Televisi dan Film, Fakultas Seni dan Desain, Universitas Potensi Utama \\ ryan.potensiutama@gmail.com
}

\begin{abstract}
ABSTRAK
Penelitian ini bertujuan untuk mendeskripsikan proses ekranisasi perbandingan interpretasi penokohan yang baik, dalam bentuk kategorisasi aspek penciutan, penambahan, maupun perubahan bervariasi dalam ekranisasi novel ke bentuk film 99 Cahaya di Langit Eropa karya Hanum Salsabiela Rais dan Rangga Almahendra. Metode penelitian yang digunakan adalah deskriptif kualitatif. Sumber data penelitian ini adalah novel 99 Cahaya di Langit Eropa karya Hanum Salsabiela Rais dan Rangga Almahendra dan film 99 Cahaya di Langit Eropa sutradara Guntur Soeharjanto. Penelitian berupa proses ekranisasi hanya penokohan. Instrumen penelitian ini adalah human instrument. Data diperoleh dengan teknik membaca, teknik menonton, dan teknik mencatat. Validitas data diperoleh dengan menggunakan validitas semantis dan validitas referensial, reliabilitas data diperoleh dengan menggunakan reliabilitas intrarater dan reliabilitas interrater. Hasil penelitian ini menunjukkan bahwa proses ekranisasi yang terjadi pada penokohan saja, yaitu adanya penciutan, penambaham, dan perubahan bervariasi. Penciutan penokohan atau tokoh terjadi karena media yang digunakan dalam pembuatan novel dan film berbeda. Secara keseluruhan penciutan yang dilakukan dalam visualisasinya ke bentuk film masih sesuai dilakukan karena terdapat penghilangan cerita, tokoh atau penokohan diambil pada bagian yang tidak begitu penting untuk divisualisasikan. Penambahan penokohan atau tokoh dalam film secara keseluruhan masih relevan dangan cerita yang ada dalam novel, hanya saja pada visualisasi dalam film dibuat lebih menarik dengan banyaknya adanya tokoh tambahan yang dimunculkan sehingga cerita dalam film tidak monoton seperti dalam novel. Kemunculan tersebut untuk menambah esensi film sehingga penonton akan terbawa masuk dalam alur cerita. Adapun untuk perubahan bervariasi tokoh yang dilakukan dalam visualisasinya ke bentuk film secara keseluruhan tidak jauh melenceng dari penggambaran yang ada pada novel.
\end{abstract}

Kata Kunci : Interpretasi Penokohan, Film Cahaya Dilangit Eropa, Novel.

\begin{abstract}
This study aims to describe the process of ekranisasi comparison interpretation of good characterizations, in the form of categorization of aspects of shrinking, adding, and varying changes in the novelization of the novel into the form of the film 99 Cahaya di Langit Eropa by Hanum Salsabiela Rais and Rangga Almahendra. The research method used is descriptive qualitative. The data source of this study is the novel 99 Cahaya di Langit Eropa by Hanum Salsabiela Rais and Rangga Almahendra and the film 99 Cahaya Di Langit Eropa director Guntur Soeharjanto. Research in the form of the process of ekranisasi only characterization. The instrument of this research is human instrument. Data is obtained by reading techniques, watching techniques, and recording techniques. Data validity was obtained using semantic validity and referential validity, the reliability of the data was obtained by using intrarater reliability and interrater reliability. The results of this study indicate that the process of ekranisasi that occurs in characterizations only, namely the existence of shrinking, understanding, and changes vary. Decreasing characterizations or figures occur because the media used in making novels and films is different. Overall, the shrinkage carried out in the visualization into the form of the film is still appropriate because there
\end{abstract}


are omissions of stories, characters or characterizations taken in parts that are not so important to visualize. The addition of characterizations or figures in the film as a whole is still relevant to the stories in the novel, except that the visualization in the film is made more interesting by the number of additional characters that are raised so that the story in the film is not monotonous as in the novel. The appearance is to add to the essence of the film so that the audience will be carried into the storyline. As for the varied changes the characters performed in their visualization to the film's shape as a whole are not far off the mark of the novel.

Keywords: Interpretation of Characterizations, Films, Novels.

\section{PENDAHULUAN}

Fenomena perubahan karya sastra ke dalam bentuk film telah terjadi sejak beberapa dekade. Sejumlah film yang sukses, khususnya dari segi jumlah penonton dan apresiasi masyarakat, merupakan film yang diangkat dari karya sastra khususnya novel. Dalam artikel yang ditulis oleh Suseno disebutkan bahwa dalam sejarah perfilman dunia, Hollywood misalnya, sembilan puluh persen skenario film dan televisi berasal dari perubahan karya sastra. Beberapa judul karya yang diangkat dari novel ke dalam bentuk film, antara lain: The Old Man and The Sea karya Ernest Hemingway, Dr. Zhivago karya Boris Pasternak, In The Name of the Rose karya Umberto Eco, The God Father I, II, III karya Mario Puzo, The Lord of the Ringskarya Tolkien, dan Harry Potter karya JK Rowling.

Sementara itu, di Indonesia perubahan karya sastra ke dalam bentuk film juga telah lama dilakukan. Setidaknya, pada tahun 1951 telah dilakukan proses adaptasi dari novel ke dalam bentuk film yaitu ketika sutradara Huyung memfilmkan drama yang berjudul Antara Bumi dan Langit karya Armijn Pane (Eneste, 1991:9).

Beberapa novel yang pernah diangkat ke dalam bentuk film antara lain Sengsara Membawa Nikmat karya Tulis Sutan Sati dengan sutradara Agus Wijoyono, Roro Mendut karya Y.B. Mangunwijaya dan Darah dan Mahkota Ronggeng yang diadaptasi secara lepas dari novel trilogi Ronggeng Dukuh Paruk tahun 1982 karya Ahmad Tohari dengan sutradara Ami Prijono, Atheis karya Achidat Karta Miharja dan Si Doel Anak Betawi karya Aman Datuk Majoindo dengan sutradara Sjuman Djaya, Salah Asuhan karya Abdoel Moeis dengan sutradara Asrul Sani, Cintaku di Kampus Biru karya Ashadi Siregar dengan sutradara Ami Prijono, Badai Pasti Berlalu karya Marga T. dengan sutradara Teguh Karya (1977) dan difilmkan kembali oleh Teddy Soeriaatmaja (2007), Lupus karya Hilman Hariwijaya yang kemudian diproduksi lagi pada tahun 2013 dengan judul Bangun Lagi Dong Lupus dengan sutradara Benni Setiawan, hingga ke novel-novel religi seperti Ayat-Ayat Cinta karya Habiburrahman El Shirazy dan Perempuan Berkalung Sorban karya Abidah El Khalieqy dengan sutradara Hanung Bramantyo.

Proses perubahan dari novel menjadi film atau sebaliknya dari film menjadi novel, dari novel menjadi sinetron dan dari cerpen menjadi film memang dibutuhkan imajinasi dalam proses penggarapannya. Eagleton (via Faruk, 2001:35) mengatakan bahwa imajinasi adalah produk kekuatan spiritual manusia yang subjektif, yang tidak dapat dibatasi, tidak hanya oleh realitas melainkan bahkan oleh kontrol pikiran sadar manusia. Dari hal itulah muncul gagasan mengenai otonomi karya sastra sebagai representasi yang paling sempurna dari kekuatan imajinasi tersebut. Oleh sebab itu dalam proses adaptasi memang diperlukan adanya imajinasi sehingga bisa jadi akan terdapat perubahan-perubahan dalam proses adaptasi tersebut. Perubahan-perubahan tersebut memang wajar dilakukan dan mau tidak mau tentu dalam pembuatan film memang akan dilakukan perubahan di sana-sini. Dengan demikian, akan terjadi perubahan fungsi film, yaitu bahwa film bukan lagi merupakan sentral 
budaya tetapi film telah menjadi bagian dari budaya pop lainnya, seperti buku, musik, dan lain-lain (Nugroho, 1995:154).

Eneste (1991: 9-10) berpendapat bahwa penonton biasanya kecewa setelah melihat film karena filmnya tidak seindah pada novel, jalan ceritanya tidak sama dengan novel, karakter tokoh dalam film tidak sama dengan novel, atau banyaknya perubahan yang terjadi dalam film yang membuatnya tidak sama dengan novel slinya. Selain penonton, penulis novel pun tidak jarang merasakan ketidakpuasan terhadap film yang diadaptasi dari novel mereka. Motinggo Busye merupakan pengarang yang terdorong langsung untuk terjun ke dunia film karena merasa kecewa dengan skenario (naskah film) yang didasarkan pada lakonnya, Malam Jahanam. Armijn Pane pun mengalami kekecewaan yang sama terhadap dramanya yang berjudul Antara Bumi dan Langit ketika diangkat ke layar lebar oleh sutradara Huyung. Karena pertimbangan komersial, dalam film tersebut nilai sastra yang terkandung dalam novel tidak terungkap lagi bahkan menjadi rusak sama sekali. Oleh sebab itu, Armijn Pane tidak bersedia namanya dicantumkan sebagai penulis asli cerita Antara Bumi dan Langit.

Dalam melakukan perubahan terhadap novel yang diadaptasi menjadi film tentu membutuhkan proses kreatif. Eneste (1991:61-65) mengatakan proses kreatif dalam pengangkatan novel ke layar lebar dapat berupa penambahan maupun pengurangan jalannya cerita. Hal tersebut terkait dengan faktor narasi tetapi dengan tidak mengesampingkan faktor estetik. Proses kreatif tersebut yang diterapkan sutradara Guntur Soeharjanto dalam pengangkatan novel ke layar lebar yang berjudul 99 Cahaya di Langit Eropa. Proses adaptasi dari novel karya Hanum Salsabiela Rais dan Rangga Almahendra ke bentuk film garapan sutradara Guntur Soeharjanto inilah yang akan menjadi objek kajian dalam penelitian ini.

Hanum Salsabiela Rais, lahir dan menempuh pendidikan dasar Muhammadiyah di Yogyakarta kemudian melanjutkan pendidikannya ke jenjang perkuliahan hingga mendapatkan gelar Dokter Gigi dari Fakultas Kedokteran Gigi Universitas Gadjah Mada. Hanum mengawali karir menjadi jurnalis dan presenter di TRANS TV dan juga tercatat sebagai koresponden detik.com bagi kawasan Eropa dan sekitarnya. Dalam situs resminya http://www.hanumrais.com, juga disebutkan bahwa pada tahun 2010 Hanum menerbitkan buku pertamanya yang berjudul Menapak Jejak Amien Rais: Persembahan Seorang Putri untuk Ayah Tercinta. Selain itu, Hanum juga menulis novel yang berjudul Bulan Terbelah di Langit Amerika,Berjalan di Atas Cahaya, dan 99 Cahaya di Langit Eropa. Sementara itu, Rangga Almahendra adalah penulis kedua buku ini yang juga sekaligus suami dari Hanum. Rangga menamatkan pendidikan dasar hingga menengah di Yogyakarta kemudian melanjutkan kuliah program S1 di Institut Teknologi Bandung dan S2 di Universitas Gadjah Mada. Saat ini Rangga tercatat sebagai dosen di Johannes Kepler University dan Universitas Gadjah Mada.

Film 99 Cahaya di Langit Eropa merupakan film Maxima Pictures yang bias dibilang film mahal karena dalam pembuatannya dilakukan di luar negeri. Dalam pemutarannya, film 99 Cahaya di Langit Eropa menempati posisi kedua dari sepuluh film yang ditayangkan pada tahun 2013 dengan jumlah penonton sekitar 1.189 .709 orang. Adapun film 99 Cahaya di Langit Eropa bagian 2 menempati posisi keenam dari sepuluh film yang ditayangkan pada tahun 2014 dengan jumlah penonton sekitar 587.042 orang (http://filmindonesia.or.id).

Novel 99 Cahaya di Langit Eropa merupakan novel yang menyimpan banyak pengetahuan terutama pengetahuan tentang sejarah Islam di Eropa sehingga penulis tertarik untuk mengkaji novel tersebut. Pemilihan novel 99 Cahaya di Langit Eropadidasarkan pada beberapa alasan. Pertama, respon masyarakat cukup besar terhadap novel 99 Cahaya di Langit Eropa sehingga telah dicetak hingga belasan kali dan banyak juga yang membahas atau meresensi novel tersebut di media masa mulai dari situs resmi hingga oleh penulispenulis yang mengulasnya pada blog pribadinya. Kedua, novel 99 Cahaya di Langit Eropa telah ditransformasikan ke dalam bentuk komik pada tahun 2014 dengan jumlah 76 halaman 
dan diterbitkan oleh PT Maleo Creative, Jakarta. Beberapa alasan tersebut yang membuat penulis tertarik untuk mengkaji novel 99 Cahaya di Langit Eropa. Namun, dalam pengkajian ini penulis lebih memfokuskan pada proses ekranisasi novel ke dalam bentuk film. Pengkajian yang dilakukan difokuskan pada unsur-unsur intrinsik antara novel dan film 99 Cahaya di Langit Eropa. Unsur intrinsik yang akan dibahas hanya terfokus pada alur, tokoh dan latar karena ketiga unsur tersebut dirasa sudah cukup mewakili. Dalam penelitian ini, teori yang digunakan untuk menganalisis proses ekranisasi novel ke dalam bentuk film adalah teori ekranisasi.

Eneste (1992:60-61) mengatakan bahwa yang dimaksud dengan ekranisasi adalah pelayarputihan atau pemindahan/pengangkatan sebuah novel ke dalam film (ecran dalam bahasa Prancis berarti layar). Dalam proses ekranisasitentu akan menimbulkan berbagai perubahan. Perubahan yang terjadi antara lain perubahan pada alat-alat yang dipakai, perubahan pada proses penggarapan, juga perubahan pada proses penikmatan.

Eneste (1991:61-66) juga mengatakan pemindahan dari novel ke layar lebar atau film juga mau tidak mau akan menimbulkan proses penciutan, penambahan dan perubahan bervariasi. Pada proses penciutan akan terjadi pemotongan peristiwa, ada juga beberapa tokoh dan latar yang tidak ditampilkan karena dirasa tidak penting untuk ditampilkan dalam film. Salah satu contoh pemotongan peristiwa terjadi pada bagian ketika Hanum dan Rangga berkunjung ke istana Al-Hambra di Granada. Dalam novel diceritakan bahwa setelah mengunjungi Mezquita di Cordoba, Hanum dan Rangga kemudian ke Granada untuk mengunjungi istana Al-Hambra tetapi dalam film tidak ditampilkan cerita tersebut.

Dalam proses penambahan juga bisa terjadi pada alur, tokoh, dan latar. Dalam film 99 Cahaya di Langit Eropa juga terjadi adanya penambahan tokoh, yaitu adanya tokoh Fatin. Saat itu, Hanum dan Rangga yang turun dari bukit Kahlenberg bertemu dengan Fatin yang sedang melakukan shooting video klip. Proses perubahan bervariasi juga terjadi dalam alur, tokoh, dan latar. Salah satu contoh perubahan bervariasi latar yaitu penggambaran suasana saat berada di museum Wina. Dalam novel diceritakan bahwa saat Hanum terpisah dengan Fatma, lampu museum dalam keadaan padam sedangkan dalam film digambarkan bahwa lampu museum tidak padam. Beberapa perubahan tersebut yang nantinya akan dibahas dalam penelitian ini karena memang dalam proses ekranisasi dari novel ke dalam bentuk film mau tidak mau akan menimbulkan berbagai perubahan. Perubahan dalam pembuatan film memang bisa saja terjadi karena berbagai alasan. Misalnya saja dikatakan bahwa perubahan tersebut penting dilakukan jika dilihat dari sudut pandang filmis. Selain itu ada juga alasan bahwa perubahan tersebut masih relevan dengan jalannya cerita secara keseluruhan (Eneste, 1991:64-65).

\section{STUDI LITERATUR}

Dalam penulisan ini, penulis banyak melakukan studi literatur pada buku-buku yang berkaitan tentang film mengenai perbandingan novel dan film dengan menggunakan salah satunya yakni teori ekranisasi, tesis, jurnal dan penelitian yang telah dilakukan oleh pengkarya sebelumnya. Data yang di dapat dari studi literatur ini akan digunakan sebagai acuan dalam jurnal

\section{PEMBAHASAN}

Secara keseluruhan, dalam proses ekranisasi novel ke bentuk film 99 Cahaya di Langit Eropa yang dilakukan pada unsur alur, tokoh, dan latar menunjukkan adanya proses penciutan, 
penambahan, dan perubahan bervariasi. asil dari penelitian tersebut yaitu dalam proses ekranisasi alur pada kategorisasi aspek penciutan ditemukan data sebanyak 13 bagian dalam novel yang tidak ditampilkan dalam film. Kategorisasi aspek penambahan ditemukan data sebanyak 37 penambahan scene dalam film. Adapun untuk kategorisasi aspek perubahan bervariasi ditemukan data sebanyak 18 perubahan bervariasi yang dilakukan pada visualisasinya ke bentuk film.

Dalam proses ekranisasi tokoh pada kategorisasi aspek penciutan ditemukan data sebanyak enam tokoh yang tidak ditampilkan dalam film. Kategorisasi aspek penambahan ditemukan data sebanyak tujuh penambahan tokoh dalam film. Adapun untuk kategorisasi perubahan bervariasi tokoh ditemukan data sebanyak enam perubahan bervariasi tokoh. Dalam proses ekranisasi latar pada kategorisasi aspek penciutan ditemukan data sebanyak Sembilan latar yang tidak ditampilkan dalam film. Kategorisasi aspek penambahan ditemukan data sebanyak tujuh penambahan latar dalam film. Adapun untuk kategorisasi perubahan bervariasi latar hanya ditemukan satu data perubahan bervariasi latar.

\section{III.1. Teori Ekranisasi (Eneste)}

Ekranisasi menurut Eneste (1991: 60) adalah suatu proses pelayar putihan atau pemindahan atau pengangkatan sebuah novel ke dalam film. Adaptasi novel ke layar putih mengakibatkan timbulnya berbagai perubahan. Perubahan yang terjadi dalam proses ekranisasi dijelaskan secara rinci oleh Eneste. Eneste (1991: 61) menyatakan bahwa pengurangan dilakukan dalam unsur karya sastra seperti cerita, alur, tokoh, latar, maupun suasana. Dengan adanya proses pengurangan atau pemotongan maka tidak semua hal yang diungkapkan dalam novel akan dijumpai pula dalam film. Penambahan (perluasan) adalah perubahan dalam proses transformasi karya sastra ke bentuk film. Sebagaimana halnya dalam kreasi pengurangan, dalam proses ini juga bisa terjadi pada ranah cerita, alur, penokohan, latar, maupun suasana.

Menurut Eneste (1991: 65), ekranisasi memungkinkan terjadinya variasi-variasi tertentu antara novel dan film. Eneste (1991: 61-66) juga mengatakan pemindahan dari novel ke layar lebar atau film mau tidak mau akan menimbulkan berbagai perubahan dalam film, perubahan tersebut seperti Penciutan, Penambahan, dan Perubahan Bervariasi. Secara Ekranisasi, ekranisasi sebagai layar putihan (Ecran dalam bahasa Perancis berarti Layar). Pemindahan novel ke layar putih mengakibatkan timbulnya berbagai perubahan. Oleh sebab itu, dapat dikatakan bahwa ekranisasi adalah proses perubahan (Eneste, 1999:60).

\section{III.2. Interpretasi}

Hanum dan Rangga sebagai penulis novel ini, menjadikan pengalaman mereka untuk membuat novel ini agar seluruh pembaca novel ini dapat mengerti kebesaran allah dan keagungan serta kemuliaan Islam. Dalam cerita ini, benar-benar membuat kita terpesona akan indahnya islam, dimana penulis novel ini sendirilah yang merasakan hidup di negara Eropa yang minoritas agamanya adalah Islam. Perjalanan mereka juga merupakan suatu pengalaman yang memperkaya nilai spiritual untuk lebih memaknai Islam.

Ada banyak kisah perjalanan menarik yang juga dapat menambah pengetahuan kita tentang peninggalan-peninggalan islam di Eropa, dan itu sangat menarik.Pada saat Hanum dan Fatma mengunjungi Museum Kota Wina, disana terdapat banyak sekali peninggalan Islam di Eropa, salah satunya adalah lukisan Kara Mustafa Pasha, seorang panglima perang Turki yang gagal mempertahankan Islam namun kerja keras beliau sangatlah besar.

Ketika Hanum dan Rangga mengunjungi paris, mereka bertemu dengan seorang mualaf, Marion Latimer yang bekerja sebagai ilmuwan di Arab World Institute Paris. Marion 
menunjukkan kepadaku bahwa Eropa juga adalah pantulan cahaya kebesaran Islam. Salah satunya Museum Louvre, dimana terdapat lafal "Lailahailallah" pada kerudung lukisan bunda Maria. Di Pantheon, Gereja Notre Dame hingga Les Invalides yang menyimpan banyak sejarah Islam semakin membuat kami yakin dengan agama Islam.

Hal yang menarik menurut kami juga ketika Hanum dan Rangga mengunjungi Cordoba. Disana terdapat sebuah bangunan Mezquita atau Masjid Córdoba, sebuah gereja katedral di Spanyol yang dahulu merupakan sebuah masjid. Masjid itu pertama kali dibangun oleh Khalifah Muslim Abdurahman I pada tahun 787. Córdoba adalah ibukota Spanyol di bawah pemerintahan dinasti Umayyah. Pada saat pemerintahan Umayyah.

Dan perjalanan terakhir yang tidak kalah menariknya adalah saat mereka menuju Turki, mereka bertemu dengan fatma di Hagia Sophia. Haga Shopia di bangun pada abad 8 lalu yang berfungsi sebagai Katedral, namun setelah sultan ahmad kedua berkuasa di Turki, bangunan ini kemudian di alih fungsikan menjadi masjid, dan kini telah djadikan sebuah museum oleh pemerintah Turki

Selain perjalanan-perjalanan menjajali sejarah islam di Eropa, pada film ini juga ada terjadi beberapa konflik yang memang sangat menguras perasaan, salah satunya adalah dimana konflik rumah tangga terjadi antara Rangga dan Hanum, ketika Maria yang selalu medekati rangga hingga Hanum benar-benar cemburu, namun dengan saling percaya satu sama lain, Hanum dan Rangga dapat mengembalikan keharmonisan rumah tangganya bersama Hanum. Konflik lain yang menarik juga terjadi antara Khan dan Steffan, dimana dua orang teman ini yang selalu berdebat perihal perbedaan keyakinan yang sangat mendasa antara mereka, hingga suatu ketika musibah menimpa keduanya, dan disitulah mulai terjalin hubungan persahabatan antara mereka, meski berbeda keyakinan namun pada akhirnya mampu saling untuk saling mengerti dan memahami satu sama lain.

\section{III.3. Proses Ekranisasi Penokohan dalam Novel dan Film 99 Cahaya di Langit Eropa}

Tokoh utama adalah tokoh yang diutamakan penceritaannya dalam cerita. Tokoh utama merupakan tokoh yang paling banyak diceritakan, baik sebagai pelaku kejadian maupun yang dikenai kejadian. Karena tokoh utama paling banyak diceritakan dan selalu berhubungan dengan tokoh-tokoh yang lain, ia sangat menentukan perkembangan plot secara keseluruhan. Di samping itu, selain adanya pemunculan tokoh utama terdapat pula tokoh tambahan. Pemunculan tokoh-tokoh tambahan dalam keseluruhan cerita tentu lebih sedikit, tidak terlalu dipentingkan, dan kehadirannya jika hanya ada kaitannya dengan tokoh utama baik itu secara langsung maupun tidak langsung (Nurgiyantoro, 1998:176-177).

Menurut Sudjiman (via Budianta, 2002:86), tokoh adalah individu rekaan yang mengalami peristiwa atau berkelakuan dalam berbagai peristiwa dalam cerita. Tokoh-tokoh dalam sebuah fiksi dapat dibedakan ke dalam beberapa jenis penamaan berdasarkan dari sudut mana penamaan itu dilakukan. Salah satunya adalah tokoh utama dan tokoh tambahan.

\section{A. Aspek Penciutan}

Dalam hasil penelitian yang telah disajikan, untuk kategori aspek penciutan tokoh berjumlah 6 tokoh. Penciutan 6 tokoh tersebut terdapat dalam 8 bagian yang berbeda dalam novel. Bagian-bagian tersebut antara lain: petugas museum Wina pada B8, Oznur pada B9, Hasan pada B37, Sergio pada B41, Luiz pada B42, dan Ranti Tobing pada B49. Kategori aspek penciutan tokoh ini dilihat dari tidak ditampilkannya tokoh-tokoh dalam bagian novel tersebut ke dalam film. 
Berikut salah satu data yang menunjukkan adanya proses penciutan yaitu dihilangkannya tokoh Hasan. Saat Hanum dan Rangga berada di Cordoba, terjadi penciutan alur saat mengunjungi kedai Hasan dan berkeliling di sekitar Mezquita. Oleh sebab itu secara otomatis terjadi penciutan tokoh Hasan pada bagian tersebut. Berikut kutipan yang menunjukkan adanya tokoh Hasan dalam novel.

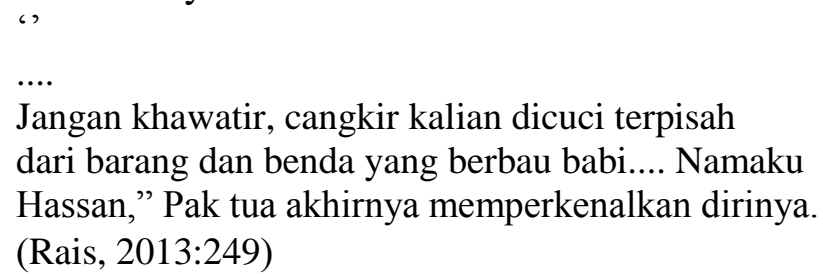

Kutipan di atas merupakan kutipan dalam novel pada B37 yang memunculkan tokoh Hasan. Tokoh Hasan dalam novel diceritakan sebagai seorang muslim yang menjual daging babi. Saat itu Hanum dan Rangga yang akan berkunjung ke Mezquita memotret Hasan saat sedang melakukan aktivitasnya berjualan daging babi. Hasan yang mengetahui hal tersebut meminta Hanum dan Rangga untuk berkunjung di kedainya. Saat itulah Hasan menceritakan bahwa dia merupakan seorang muslim dan pilihannya menjual daging babi dikarenakan sangat sulit mencari pekerjaan di Spanyol.

\section{B. Aspek Penambahan}

Dalam tabel hasil penelitian yang telah disajikan, untuk kategori aspek penambahan tokoh berjumlah 7 tokoh. Penambahan 7 tokoh tersebut muncul ada 17 scene dalam film. Pembagian scene tersebut antara lain: muncul pada S21, 103, dan S113, tokoh Guru Ayse muncul pada S7, S9, dan S54, tokoh Leon muncul pada S7, S69, S72, dan S88, tokoh Alex muncul pada S12, S30, dan S37, tokoh Fatin muncul pada S56, tokoh Ayah Khan muncul pada S57 dan S101, dan tokoh Ibu Khan muncul pada S101. Kategori aspek penambahan tokoh ini dilihat dari munculnya tokoh-tokoh dalam film dan tokoh tersebut tidak terdapat dalam novel.

Data yang menunjukkan adanya proses penambahan tokoh yaitu ditambahkannya tokoh Prof. Reinhard. Prof. Reinhard merupakan dosen di kampus Rangga yang merekomendasikannya mendapatkan beasiswa untuk melanjutkan studi di Austria. Pada S21 menggambarkan pemunculan tokoh Prof. Reinhard dalam film ketika memberitahu Rangga bahwa dia menyukai riset yang dilakukan oleh Rangga dan meminta Rangga untuk mempresentasikannya di Paris. Saat itu kedatangan Rangga adalah untuk membicarakan menegenai ujian yang diadakan pada hari Jum'at. Selain S21, terdapat 2 scene yang menunjukkan pemunculan tokoh Prof. Renhard yaitu S103 dan S113. Pada S103 menunjukkan pemunculana tokoh Prof. Reinhard pada saat Rangga meminta ijin kepada Prof. Reinhard supaya Khan maju ujian desetasi terlebih dahulu menggantikan dirinya. Adapun pada S113 menunjukkan pemunculan tokoh Prof.Reihard pada saat memberi ucapaan selamat kepada Rangga atas pidatonya pada saat acara wisuda.

\section{Aspek Perubahan Bervariasi}

Dalam tabel hasil penelitian yang telah disajikan, untuk kategori aspek perubahan bervariasi berjumlah 7 tokoh. Kategori aspek perubahan bervariasi dilihat dari adanya perubahan penggambaran tokoh dalam film. Tokoh Hanum pada B2 divariasi dalam S14, pada B15 divariasi dalam S33, pada B38 divariasi dalam S96, dan pada B51 divariasi dalam S116. Tokoh Fatma pada B8 divariasi dalam S23, pada B51 divariasi dalam S116. Tokoh Aisye pada B1 divariasi dalam S7, dan B2 divariasi pada S14. Tokoh Latife dan Ezra pada B9 
divariasi dalam S26. Tokoh Hashim pada B15 divariasi dalam S33, dan tokoh Baran pada B51 divariasi dalam S116.

Data yang menunjukkan adanya proses perubahan bervariasi tokoh yaitu perubahan bervariasi pada tokoh Hanum. Dalam perubahan bervariasi pada tokoh Hanum terdapat perubahan penampilan tokoh. Perubahan terjadi pada saat bertemu dengan Imam Hashim di Viena Islamic Centre. Dalam novel pada B15 diceritakan bahwa Hanum tidak memakai kerudung ssaat Imam Hashim datang menemuinya. Saat itu Imam Hashim meminta Hanum memakai kerudung saat memasuki masjid. Perubahan bervariasi muncul dalam film, pada S33 visualisasi tokoh Hanum mengalami perubahan yaitu sudah memakai kerudung saat bertemu dengan Imam Hashim di Viena Islamic Centre.

\section{III.4. Perbandingan Antara Novel Dan Film 99 Cahaya Dilangit Eropa}

Adapaun tokoh didalam film 99 Cahaya Dilangit Eropa sebagai berikut :

1. Hanum

2. Rangga

3. Fatma

4. Ayse

5. Stevan

6. Khan

7. Maria

8. Mariom

9. Proffesor Reinhart

10. Ayah Khan

11. Ibu Khan

Dari cerita narasi yang terdapat didalam film, film memiliki banyak pesan sosial yang akan disampaikan, yang dapat dilihat pada unsur-unsur visualisasinya, termasuk karakter penokohan yang diciptakan. Dalam sebuah film banyak ditampilkan makna-makna yang tidak terlihat yang dikemas dalam keragaman tanda-tanda. Karakter penokohan bisa disebut tanda. Karena karakter adalah interpretasi suatu latar belakang perilaku yang ada pada diri seseorang individu maupun individu sebagi yang mewakili sebuah kelompok. Salah satunya didalam film 99 Cahaya Dilangit Eropa yang memiliki penokohan seperti :

a. Hanum: Teguh pada pendirian, mandiri, istri yang baik, optimis Contohnya: ketika Hanum bertekad untuk menyemangati Ayse yang dibuli oleh temannya.

b. Rangga: Pintar, sabar, setia, taatkepada agama, baikhati, ramah. Contohnya: ketika Ia tetap setia kepada Hanum disaat Marya menyukainya.

c. Fatma: Penuh perjuangan, sabar, baikhati, ramah, mudahbergaul, optimis dalam memperkenalkan sejarah islam. Contohnya: ketika Fatma memperkenalkan dan membeitahukan Hanum tentang sejarah dan peradaban islam di Eropa.

d. Ayse: Semangat, ceria, periang, baik hati, sabar.

Contohnya: ketika Ayse sedang dibuli oleh temannya karena memakai hijab, Ia tetap mempunyai semangat yang besar untuk tetap menggunakan hijab.

e. Stevan: Penuh ingin tahu, suka meremehkan, setia pada teman. Contohnya: ketika Rangga dan Khan melaksanakan ibadah, Ia selalu bertanya dan terkadang meremehkan kepercayaan orang lain.

f. Khan: Optimis, berbakti kepada orangtua, baikhati, emosian, suami yang baik. Contohnya: ketika Ayah Khan memutuskan Khan berjihad dengan ilmu, Ia menuruti kemauan ayahnya dan ketika Ia tidak menyukai kari namun Ia setiap hari memakan kari yang dibuatkan oleh istrinya.

g. Maria: Ramah, baik, lapang dada, pintar, semangat dalam segala hal, pantang menyerah. 
Contohnya: ketika Ia merelakan Rangga yang telah mempunyai istri dan menyikapinya dengan lapang dada serta tetap bersikap ramah terhadap Rangga dan Hanum.

h. Marion: Baik hati, muslim sejati, ramah, bersahabat.

Contohnya: Ketika Ia mengajak Hanum berkeliling kota Paris dan memperkenalkan sejarah perkembangan islam di Paris.

i. Proffesor Reinhart: Tegas, teguh pada pendirian.

Contohnya:ketika Ia menetapkan bahwa jadwal ujian pada hari jumat dan pada waktu sholat jumat meskipun Rangga dan Khan telah meminta pergantian waktu.

j. Ayah Khan: Optimis, rela berkorban, penyayang. Contohnya: ketika Ia dengan gigih melindungi keluarganya serta Khan.

Tabel.1. Perbandingan Penokohan Antara Novel Dan Film 99 Cahaya Dilangit Eropa

\begin{tabular}{|c|c|}
\hline Novel & Film \\
\hline $\begin{array}{l}\text { Kisah Kara Mustafa Pasha didalam } \\
\text { novelnya digambarkan dengan cara } \\
\text { menceritakan kisah Kara Pasha dengan } \\
\text { sudut pandang Kara Pasha sendiri } \\
\text { sebagai pimpinan perang yang gagal } \\
\text { mempertahankan Islam di Eropa. }\end{array}$ & $\begin{array}{l}\text { Didalam filmnya kisah Kara Mustafa } \\
\text { Pasha hanya berupa deskripsi, dengan } \\
\text { beberapa kalimat singkat yang } \\
\text { ditayangkan pada awal dimulainya film. }\end{array}$ \\
\hline $\begin{array}{l}\text { Ayse putri semata wayang Fatma dan } \\
\text { Selim didalam novel digambarkan } \\
\text { sebagai balita berumur } 3 \text { tahun. }\end{array}$ & $\begin{array}{l}\text { Ayse putri semata wayang Fatma dan } \\
\text { Seling didalam novel digambarkan } \\
\text { sebagai anak berusia } 9 \text { tahun, dan } \\
\text { menjadi siswa disalah satu sekolah di } \\
\text { kota Wina, Austria. }\end{array}$ \\
\hline $\begin{array}{l}\text { Fatma di dalam novel sempat } \\
\text { memperlihatkan kepada Hanum dari } \\
\text { atas Bukit kahlenberg dimana letak } \\
\text { Masjid yang bernama Vienna Islamic } \\
\text { Center }\end{array}$ & $\begin{array}{l}\text { Dalam film tidak ada masjid yang } \\
\text { bernama Vienna Islamic Center }\end{array}$ \\
\hline $\begin{array}{l}\text { Didalam novel tidak ada karakter } \\
\text { bernama Leon }\end{array}$ & $\begin{array}{l}\text { Didalam film Leon merupakan anak } \\
\text { laki-laki asli Wina yang berperan } \\
\text { sebagai teman sekelas Ayse, yang kerap } \\
\text { kali mengejek Ayse yang selalu } \\
\text { memakai kerudung ke sekolah. }\end{array}$ \\
\hline $\begin{array}{l}\text { Konflik batin yang dirasakan Hanum } \\
\text { didalam Novel lebih dominan, dari pada } \\
\text { konflik yang di alami Rangga. }\end{array}$ & $\begin{array}{l}\text { Dalam film } 99 \text { Cahaya Di langit Eropa, } \\
\text { konlik yang di alami Rangga lebih } \\
\text { ditonjolkan. Jadi ada keseimbangan } \\
\text { antara cerita kehidupan Rangga dan } \\
\text { Hanum di Wina. Didalam film untuk } \\
\text { mewujudkannya tokoh pendukung Khan } \\
\text { dan Stefen di munculkan. }\end{array}$ \\
\hline $\begin{array}{l}\text { Tidak ada karakter wanita bernama } \\
\text { Marya }\end{array}$ & $\begin{array}{l}\text { Marya didalam film digambarkan } \\
\text { sebagai salah seorang teman } \\
\text { seuniversitas Rangga di Wina, yang } \\
\text { diamna menaruh hati kepada Rangga. } \\
\text { Diakibatkan oleh Marya ini lah nantinya } \\
\text { pasangan Hanum Rangga di berikan } \\
\text { cobaan dalam kehidupan asmara } \\
\text { mereka. }\end{array}$ \\
\hline
\end{tabular}




\begin{tabular}{|c|c|}
\hline $\begin{array}{l}\text { Teman-teman Fatma yang ia } \\
\text { perkenalkan kepada Hanum ada } 3 \text { orang } \\
\text { yaitu Latife, Ezra, dan Oznur. }\end{array}$ & $\begin{array}{l}\text { Tokoh Oznur dalam film tidak } \\
\text { ditampilkan, hanya ada Latife dan Ezra. }\end{array}$ \\
\hline $\begin{array}{l}\text { Didalam novel diceritakan kejadian mati } \\
\text { lampu yang dialami Hanum ketika } \\
\text { berkunjung bersama Fatma dan Ayse ke } \\
\text { museum Kota Wina. Dinama ketika itu } \\
\text { Hanum sempat berpisah dengan Fatma } \\
\text { dan Ayse. }\end{array}$ & $\begin{array}{l}\text { Didalam film hanya diceritakan Hanum } \\
\text { dan Fatma terpisah, namun adegan mati } \\
\text { lampu di dalam Museum kota Wina } \\
\text { tidak ada. }\end{array}$ \\
\hline $\begin{array}{l}\text { Diceritakan pengalaman Hanum dan } \\
\text { Fatma yang menonton bersama ajang } \\
\text { Piala Dunia Grup A dimana pada saat itu } \\
\text { Turki berhadapan dengan Portugis }\end{array}$ & $\begin{array}{l}\text { Tidak diceritakan kejadian Hanum dan } \\
\text { Fatma menonton Piala dunia Group A } \\
\text { Turki Vs Potugis. }\end{array}$ \\
\hline $\begin{array}{l}\text { Didalam novel ketika melakukan } \\
\text { perjalanan ke Paris, Rangga dan Hanum } \\
\text { sejak pertama kali sampai Marion telah } \\
\text { menjadi pemandu jalan untuk mereka. }\end{array}$ & $\begin{array}{l}\text { Didalam film Rangga dan Hanum } \\
\text { bertemu Marion setelah satu hari sampai } \\
\text { di Paris. }\end{array}$ \\
\hline $\begin{array}{l}\text { Tokoh Marion Lamiter seorang peneliti } \\
\text { sejarah Islam abad pertengahan, didalam } \\
\text { novel di gambarkan sebagai salah } \\
\text { seorang Mualaf yang diperkenalkan oleh } \\
\text { Imam Hashim, penjaga Masjid Vienna } \\
\text { Islamic Center. Dikatakan Marion } \\
\text { menjadi Mualaf seelah mengetahui } \\
\text { tokoh Idolanya Napoleon Bonaparte } \\
\text { yang sebenarnya juga Islam. }\end{array}$ & $\begin{array}{l}\text { Tokoh Marion Lamiter di dalam film } \\
\text { digambarkan sebagai salah satu teman } \\
\text { Fatma, yang saat itu bertempat tinggal di } \\
\text { Paris. Dan Marion sendiri di } \\
\text { perkenalkan oleh Fatma kepada Hanum }\end{array}$ \\
\hline $\begin{array}{l}\text { Tidak ada cerita secara jelas ketika } \\
\text { Hanum dan Rangga menaiki menara } \\
\text { Eiffel bersama. }\end{array}$ & $\begin{array}{l}\text { Ada adegan dimana Hanum dan Rangga } \\
\text { jalan-jalan bersama menaiki menara } \\
\text { Eiffel dan Rangga mengumandangkan } \\
\text { Adzan dari atas sana. }\end{array}$ \\
\hline $\begin{array}{l}\text { Sebelum pergi meninggalkan Wina } \\
\text { Fatma sempat mengirim pesan kepada } \\
\text { Hanum }\end{array}$ & $\begin{array}{l}\text { Ketika menginggalkan Wina Fatma } \\
\text { tidak memperi berita apapun pada } \\
\text { Hanum. }\end{array}$ \\
\hline $\begin{array}{l}\text { Didalam novel Hanum menceritakan } \\
\text { dirinya smenjak berpisah dengan Fatma, } \\
\text { dia tidak dapat melakukan kontak lagi } \\
\text { dengan sahabat Fatma yang lain seperti, } \\
\text { Oznur, Latife, dan Ezra }\end{array}$ & $\begin{array}{l}\text { Namun di dalam Filmnya Hanum masih } \\
\text { menjalani persahabatan dengan Latife } \\
\text { dan Ezra }\end{array}$ \\
\hline $\begin{array}{l}\text { Tidak mengisahkan kenangan Khan } \\
\text { waktu kecil, ketika terjadi perang di } \\
\text { Pakistan }\end{array}$ & $\begin{array}{l}\text { Menceritakan masa kecil Khan ketika } \\
\text { kecil, yang sempat bercekcok dengan } \\
\text { Ayahnya. }\end{array}$ \\
\hline $\begin{array}{l}\text { Didalam novel konflik kehidupan } \\
\text { Rangga di Universitasnya tidak terlalu } \\
\text { ditonjolkan, hanya di ceritakan secara } \\
\text { sekilas namun mendetail oleh Hanum. }\end{array}$ & $\begin{array}{l}\text { Didalam film sempat di ceritakan } \\
\text { konflik ketika Rangga akan mengikuti } \\
\text { ujian di Universitasnya, namun harinya } \\
\text { bertepatan dengan waktu untuk sholat } \\
\text { Jumat. Rangga sempat berkonsultasi } \\
\text { dengan sang dosen namun gagal. }\end{array}$ \\
\hline $\begin{array}{llcr}\text { Kematian } & \text { Ayse } & \text { anak } & \text { Fatma } \\
\text { disampaikan } & \text { kepada } & \text { Hanum } & \text { melalui }\end{array}$ & $\begin{array}{l}\text { Kematian Ayse di sampaikan oleh } \\
\text { Fatma ke pada Hanum setelah Hanum }\end{array}$ \\
\hline
\end{tabular}




\begin{tabular}{|c|c|}
\hline $\begin{array}{l}\text { email oleh Fatma sendiri setelah sekian } \\
\text { lama menghilang. Dalam e-mail itu } \\
\text { Fatma menjelaskan pada Hanum } \\
\text {,penyebab ia menghilang tiba-tiba } \\
\text { dikarenakan Ayse yang menderita } \\
\text { kanker darah. }\end{array}$ & $\begin{array}{l}\text { dan Rangga berkunjung ke Istanbul } \\
\text { mengunjungi Fatma. Namun, sebelum } \\
\text { itu Hanum telah mengetahui penyakit } \\
\text { Ayse setelah melihat bingkisan yang } \\
\text { Marion titipkan untuk Ayse dan Fatma }\end{array}$ \\
\hline $\begin{array}{l}\text { Ada tokoh Hassan seorang muslim dan } \\
\text { Indida yang bekerja di salah satu toko } \\
\text { daging babi di Cordoba. }\end{array}$ & $\begin{array}{l}\text { Tidak ada diperlihatkan tokoh Hassan, } \\
\text { ketika Rangga dan Hanum berwisata ke } \\
\text { Cordoba. }\end{array}$ \\
\hline $\begin{array}{l}\text { Akhir cerita didalam novel } \\
\text { menggambarkan pengalaman Hanum } \\
\text { ketika melakukan perjalanan Haji ke } \\
\text { Mekah, yang ketika itu sang suami } \\
\text { Rangga tak dapat mendapingi dirinya di } \\
\text { karenakan larangan dari tempat kerja } \\
\text { Rangga yang tidak mengijinkan dirinya } \\
\text { untuk mengambil cuti. }\end{array}$ & $\begin{array}{l}\text { Akhir cerita di dalam Film menceritakan } \\
\text { ketika Hanum, Rangg, dan Fatma } \\
\text { berkunjung ke makan Ayse, di mana } \\
\text { disanalah Hanum, akirnya memutuskan } \\
\text { untuk memakai hijab dalam hidupnya. }\end{array}$ \\
\hline
\end{tabular}

\section{PENUTUP}

\section{A. Kesimpulan}

Berdasarkan hasil penelitian dan pembahasan tentang proses ekranisasi unsur interpretasi perbandingan penokohan di dalam novel 99 Cahaya di Langit Eropa karya Hanum Salsabiela Rais dan Rangga Almahendra ke bentuk film 99 Cahaya di Langit Eropa karya sutradara Guntur Soeharjanto, dapat disimpulkan sebagai berikut. Proses ekranisasi interpreetasi perbandingan penokohan secara keseluruhan terdapat perbedaan yang sangat jauh salah satunya tidak adanya penokohan atau karakter Leon, Marya dan lain-lain yang ada didalam novel, sedangkan di dalam film ada dan hanya saja pada visualisasi dalam film dibuat lebih menarik. Banyak konflik yang dimunculkan sehingga alur dalam film tidak monoton seperti dalam novel. Kemunculan konflik tersebut untuk menambah esensi film sehingga penonton akan terbawa masuk dalam alur cerita. Proses ekranisasi penokohan dalam novel ke bentuk film 99 Cahaya di Langit Eropa dilakukan karena mengikuti alur dalam film.

\section{B. Saran}

Berdasarkan kesimpulan yang telah diuraikan, dikemukakan beberapa saran sebagai berikut

1. Hasil penelitian mengenai proses ekranisasi karya sastra ke dalam film dapat dijadikan alternatif untuk menambah apresiasi sastra dan dijadikan sebagai salah satu acuan dalam upaya memperbandingkan film adaptasi dengan karya aslinya. Dengan demikian, pembaca dan penonton dapat memperhatikan perbedaan-perbedaan yang muncul di antara keduanya secara objektif.

2. Kedua, bagi penelitian selanjutnya, penelitian ini belum menggunakan transkrip film dan baru menggunakan sinopsis pada setiap scene dalam film, sehingga untuk penelitian dengan jenis yang sama yaitu transformasi karya sastra, khususnya novel ke dalam bentuk film dapat menggunakan transkrip film sebagai acuan dalam pengambilan data. 


\section{DAFTAR PUSTAKA}

[1] Eneste, Pamusuk. 1991. Novel dan Film. Flores: Nusa Indah.

[2] H.T., Faruk. 2001. Beyond Imagination: Sastra Mutakhir dan Ideologi. Yogyakarta: Gama Media.

[3] Nugroho, Garin. 1995. Kekuasaan dan Hiburan. Yogyakarta: Bentang Budaya.

[4] Moleong, Lexy J. 2008. Penelitian Kualitatif. Bandung: Remaja Rosdakarya

[5] Ratna, Nyoman Kutha. 2009. Teori, Metode, dan Teknik Penelitian Sastra. Yogyakarta: Pustaka Pelajar.

[6] Nurgiyantoro, Burhan. 2013. Teori Pengkajian Fiksi (Edisi Revisi). Yogyakarta: Gadjah Mada University Press.

[7] Sayuti, Suminto A. 2000. Berkenalan dengan Prosa Fiksi. Yogyakarta: Gama Media.

[8] Wellek, Rene dan Austin Warren. 1990. Teeori Kesusastraan (Terjemahan Melani Budianta). Jakarta: Gramedia. 